\title{
Private pensions and equity in Ireland and the UK
}

Received: 23rd April, 2002

\section{Gerard Hughes}

is a research professor at the Economic and Social Research Institute, Dublin. He has economics degrees from University College Dublin, the London School of Economics and Trinity College Dublin. His research interests are in the fields of labour economics, social policy and public finance. The Economic and Social Research Institute is a not-for-profit organisation which aims to bring the latest thinking in economics and the social sciences to bear on the actual and potential problems of society.

\begin{abstract}
The strong link between private pensions and employment status means that there is little interest in the equity of private pension arrangements since it is expected that inequality in earnings will be reproduced in inequality in pensions. Nevertheless, the equity of private pensions is an issue as governments in mainly English-speaking OECD countries subsidise their provision through the tax system, and governments in a number of EU countries are now considering this policy as a way of coping with increases in long-term pension costs due to the ageing of their populations.

The favourable tax treatment of private pensions provided in Ireland and the UK is outlined. It is shown that the annual cost of tax expenditure on pensions amounted to over 1 per cent of GDP in both countries in 1997, that it substantially exceeded the cost of their means-tested social assistance schemes and amounted to two-thirds of direct expenditure on social insurance pensions in Ireland and to one-third in the UK. Evidence relating to the distribution of pension tax expenditure shows that the present tax treatment of private pensions is inequitable, as about two-thirds of the benefits accrue to the top two income deciles in both countries and 3 per cent or less to the bottom two deciles.

Proposals for containing the cost of public pension systems in Europe by relying on greater private pension provision in the future can learn from experience in Ireland and the UK that using tax incentives to promote private pension provision could impose substantial costs on the exchequer. The regressive nature of such incentives means that all taxpayers have to pay more taxes to provide benefits which accrue overwhelmingly to higher income taxpayers.
\end{abstract}

Keywords: private pensions; public pensions; pension costs; equity; taxation; income distribution

Gerard Hughes Economic and Social Research Institute, 4 Burlington Road, Dublin 4, Ireland.

Tel: +3531667 1525; Fax: +3531668 6231; e-mail: Gerry.Hughes@esri.ie

\section{Introduction}

It is well known from sample surveys that the coverage of occupational and personal pension plans is very uneven in terms of occupation, industry, sex, age income and other characteristics. ${ }^{1,2}$ There is also evidence that workers with the same income and the same number of years service receive very different incomes in retirement because their pensions are provided by different private pension companies. ${ }^{3}$ These results can be seen as the expected outcome of job choices, variations in preferences between 
present and future consumption, differences in the income elasticity of demand for a pension, and differences in attitudes to risk. In short, private provision of pensions is not expected to be equitable in the sense that almost everyone will be a member of an occupational or personal pension plan or will receive the same pension as someone with the same work history or contribution record. Why then should we be concerned about private pensions and equity?

One of the major, yet most neglected, reasons is that some governments subsidise the provision of occupational and personal pensions through the tax system by granting tax exemptions and deferments for pension saving. They justify the more favourable tax treatment of pension saving on economic and social grounds. On economic grounds, it is argued that tax incentives encourage long-term saving by increasing the rate of return on pension investment. This raises investment and the capital stock and over time it should result in an increase in output of goods and services from which pensions can be paid in the future. ${ }^{4}$ On social grounds, it is argued that it is desirable to give tax incentives to encourage people to make provision for their own retirement. ${ }^{5}$ These arguments originated primarily in English-speaking countries (Australia, Canada, Ireland, New Zealand, the United Kingdom, and the USA) which used funded private pension schemes to provide income-related pensions to supplement the basic State pension.

Similar arguments are now being made in a number of EU countries (Finland, France, Germany, Italy, Portugal, Spain) by governments which believe that greater reliance on private funded pension schemes provides the best way of coping with increases in long-term pension costs due to projected increases in the future in the proportion of older people in the population. A striking feature of arguments for greater reliance on private pension provision is that the cost of pension tax reliefs are generally omitted from projections of the relative cost of public and private provision and that little attention is paid to the effect which redistributing income through the tax system may have on income inequality in old age. ${ }^{6-11}$

Income tax reliefs on such items of personal expenditure as pension contributions, health contributions, and mortgage repayments amount, in effect, to expenditure programmes delivered through the tax system. The term 'tax expenditure', introduced by Surrey, ${ }^{12}$ is used to indicate that these reliefs are not part of the benchmark tax system and that the foregone revenue is equivalent to direct government expenditure. It is appropriate, therefore, that policies which result in tax expenditure on private pensions should be judged by the same criteria as direct expenditure programmes and that the same equity principle should be used to evaluate their effect on the income distribution.

This paper will present evidence on the cost and distribution of tax expenditure on private pensions which indicates that the Exchequer incurs significant costs through greater reliance on private pension provision and which suggests that the tax treatment of private pension plans is inequitable. The next section presents evidence on the cost of tax expenditure on occupational pensions relative to GDP in Ireland and the UK. Following this is a section comparing the cost of their tax expenditure on private pensions to direct expenditure on public pensions. After this, the paper shows how the benefits of the tax expenditure on employee contributions to occupational schemes in Ireland and to occupational and personal pension plans 
in the UK are distributed by income group. The results are summarised at the end.

The intention in presenting data on the cost and distribution of tax expenditure on pensions for Ireland and the UK is to use them as examples to show that in countries which rely heavily on private pension provision, the costs to the Exchequer can be substantial and that implementing pensions policy through the tax system is likely to increase income inequality in old age. There are important differences in the cost and distribution of Exchequer support for private pensions in the two countries, which may be due to the greater maturity of occupational pension schemes in the UK and to the fact that there are personal pension plans in the UK but not yet in Ireland. However, it is not the purpose of this paper to make direct comparisons of the cost and distribution of pension tax expenditure between the UK and Ireland or to try and explain the differences.

\section{Estimates of the cost of pension tax reliefs in Ireland and the UK}

Pension schemes in Ireland and the UK receive favourable tax treatment by applying to the tax authorities for 'exempt approved status'. To qualify for this special status a scheme must be established under an irrevocable trust, the assets of the fund must be held apart from the employer's other assets, and disposed of in accordance with a deed of trust. As none of the government agencies responsible for the operation of occupational pension schemes publish statistics on the financial operations of these schemes, the tax authorities in Ireland and the UK have based their estimates of the cost of tax reliefs on different components of pension income flows on whatever limited information is available from different sources. Annual estimates, on a consistent basis, of the cost of the tax relief on employee contributions and of the cost of the exemption of the net income of approved funds are available for Ireland since 1980/81 and for the UK for occupational and other private pension plans since $1986 / 87 .{ }^{13,14}$

For Ireland, the most comprehensive estimate of the tax expenditure on occupational pensions is the value of the tax relief on the net income of approved superannuation funds. This is based on total contributions by employers and employees plus the investment income of the funds minus the amount paid out in pension benefits and lump sums. For the UK, Adrian Sinfield ${ }^{14}$ provides estimates of the cost of tax reliefs on employee, employer, and self-employed contributions to occupational pension schemes, personal pension schemes, Free-Standing Additional Voluntary Contribution schemes, Retirement Annuity Contracts, the investment income of funds, lump sum payments from unfunded schemes after deducting income tax receipts from pensions in payment and refunds to employers of pension surpluses. ${ }^{15}$

Table 1 shows the Revenue Commissioners estimates for Ireland of the cost of the tax reliefs on occupational pensions from 1980/81 to $1997 / 98$. Over the whole period the cost of the tax relief on the net income of approved schemes rose from $f 30 \mathrm{~m}$ to $6648 \mathrm{~m}$. Relative to GDP the cost of the favourable tax treatment of the net income of pension funds quadrupled from one-third of a percentage point in 1980 to 1.4 per cent in 1997 . Table 1 also shows the cost of tax relief on occupational and personal pensions in the UK from 1986/87 to 1997/98. In nominal terms the cost of pensions tax relief increased from $£ 6,800 \mathrm{~m}$ in 
Table 1 Revenue Commissioners' estimates of the cost of tax reliefs on the net income of approved superannuation funds in Ireland 1980/81 to 1996/97 (£m) and Inland Revenue estimates of the cost of tax reliefs on occupational and other non-state pension schemes in the UK 1986/87 to 1998/99 (£m)

\begin{tabular}{|c|c|c|c|c|}
\hline Year & $\begin{array}{l}\text { Ireland } \\
\text { Net income of } \\
\text { occupational } \\
\text { pension funds } \\
\text { (£m) }\end{array}$ & $\begin{array}{l}\text { Pension tax } \\
\text { expenditure/ } \\
\text { GDP (\%) }\end{array}$ & $\begin{array}{l}\text { UK } \\
\text { Net income of } \\
\text { private pension } \\
\text { funds ( } \mathrm{Em} \text { ) }\end{array}$ & $\begin{array}{l}\text { Pension tax } \\
\text { expenditure/ } \\
\text { GDP (\%) }\end{array}$ \\
\hline $1980 / 81$ & 30.0 & 0.32 & - & - \\
\hline 1981/82 & 35.0 & 0.31 & - & - \\
\hline 1982/83 & 40.0 & 0.30 & - & - \\
\hline $1983 / 84$ & 42.0 & 0.28 & - & - \\
\hline $1984 / 85$ & 45.0 & 0.27 & - & - \\
\hline $1985 / 86$ & 53.0 & 0.30 & - & - \\
\hline $1986 / 87$ & 62.0 & 0.32 & 6,800 & 1.77 \\
\hline $1987 / 88$ & 80.0 & 0.38 & 6,300 & 1.49 \\
\hline $1988 / 89$ & 89.0 & 0.39 & 6,800 & 1.44 \\
\hline $1989 / 90$ & 130.0 & 0.51 & 7,200 & 1.41 \\
\hline $1990 / 91$ & 200.0 & 0.70 & 7,100 & 1.28 \\
\hline $1991 / 92$ & 216.0 & 0.73 & 7,100 & 1.21 \\
\hline $1992 / 93$ & 189.0 & 0.60 & 8,000 & 1.32 \\
\hline $1993 / 94$ & 245.2 & 0.72 & 7,300 & 1.14 \\
\hline $1994 / 95$ & 344.0 & 0.94 & 10,400 & 1.53 \\
\hline $1995 / 96$ & 399.0 & 0.96 & 11,700 & 1.64 \\
\hline $1996 / 97$ & 500.0 & 1.09 & 12,100 & 1.60 \\
\hline $1997 / 98$ & 648.0 & 1.23 & 10,900 & 1.35 \\
\hline
\end{tabular}

Sources: Ireland, Annual Report of the Revenue Commissioners 1981 to 1999; UK, Sinfield ${ }^{14}$ (Table 1) and HMSO). ${ }^{16}$

$1986 / 87$ to $f 10,900 \mathrm{~m}$ in $1997 / 98$.

However, relative to GDP the cost of the reliefs in the UK fell from 1.77 per cent to 1.35 per cent. A significant part of this decline is probably attributable to the abolition of Advanced Corporation Tax in the 1997 Budget. Clearly, the cost of pension tax reliefs is substantial in both Ireland and the UK. In the UK it has fluctuated around 1.5 per cent of GDP since the mid-1980s, while in Ireland it has increased from a relatively low level at the beginning of the 1980s to attain a similar level to that in the UK at the end of the 1990s.

As the cost of Exchequer support for private pensions is substantial in both countries it is necessary to ask how it compares with the cost of Exchequer expenditure on public pension schemes and how tax expenditure on private pensions is distributed by income group. These questions are important because both the Irish and the British government have expressed concerns in recent years about the cost of their public pension systems and both governments have taken steps to try and contain its cost which involve greater reliance in the future on private pension provision. There is some information available from a variety of sources in Ireland and the UK which allow us to address these issues.

\section{Tax expenditure on occupational pensions and direct expenditure on social welfare pensions}

At the end of the 1980s it was realised that ageing of the population in the early decades of the 21 st century would increase the cost of state pension schemes in many OECD countries. Governments began to look for ways of changing the balance between state and private pension provision in an attempt to avoid raising taxes in the future. ${ }^{17}$ The British 
Government concluded ${ }^{18}$ that the balance of provision should be changed over the next 50 years from 60/40 public/private to $40 / 60$. While it projects the proportion of GDP going to pensioners to increase from 10 per cent now to about 12 per cent in 2050, such a shift is expected to reduce public expenditure on pensioners from 6 per cent to around 5 per cent of GDP and to increase private expenditure on them from 4 per cent to about 7 per cent.

The Irish Government has not adopted explicit targets for state and private provision but it is broadly following a strategy recommended by the Pensions Board ${ }^{19}$ to raise gradually the flat-rate state pension from a quarter to a third of average industrial earnings, to accumulate a national pension reserve fund for investment in financial assets selected from global financial markets, and to try and increase pension coverage on a voluntary basis by providing access to Personal Retirement Savings Accounts. ${ }^{20}$ The effect of these changes would be to increase total pension costs from 9 per cent of GNP in 1996 to 11 per cent in 2046 (see reference 19, Table 5.8). The increase would be borne by both the public and private pension systems with public pension costs increasing from 4.84 per cent of GNP to 6.24 per cent and private pension costs increasing from 4.18 per cent to 4.76 per cent of GNP. In contrast to the British government's intention to reduce the share of retirement income provided by the public pension system, the outcome in Ireland is likely to be an increase in the share of retirement income provided by the public pension system with the balance of public/private provision changing somewhat from 54/46 now to $57 / 43$ in 50 years' time.

The Pensions Board (see reference 20, p. 109) noted that 'the purpose of the fund would be to place a ceiling on the additional Exchequer contribution required for [social welfare pensions for] the foreseeable future' and it recommended that the tax treatment of individual retirement savings accounts should be more favourable than that for occupational pension funds. Neither the British or Irish governments has provided any comparisons of past trends in Exchequer expenditure on social welfare pensions relative to tax expenditure on private pensions, nor do they include in their current expenditure figures or long-term projections estimates of tax expenditure on private pensions.

The policy message which comes through the various reports published as part of the pension reviews in Ireland and Britain is that state pension schemes should be restricted to paying modest flat-rate benefits while relying on private pensions to provide more retirement income on a voluntary basis in the future. It appears to be assumed that incentives for private pension provision can be given at such little cost to the Exchequer $^{19,21}$ that they can safely be ignored in long-term projections of pension costs. This assumption will be tested by looking at the trend in the cost of tax expenditure on occupational pensions in Ireland and on occupational and personal pensions in the UK relative to the trend in direct government expenditure on social welfare pensions in both countries.

Tax expenditure on occupational pensions and direct expenditure on social welfare pensions in Ireland are compared in Table 2 for the period 1980/81 to 1997/98. At the beginning of the period in 1980, tax expenditure on occupational pensions amounted to 20 per cent of direct expenditure on contributory social insurance pensions, f30m versus f153m. By the end of the period it had increased to 98 per cent, $6648 \mathrm{~m}$ versus $661 \mathrm{~m}$. With respect to 
Table 2 Direct expenditure on state pensions, tax expenditure on occupational pensions and direct expenditure as per cent of tax expenditure on pensions, Ireland 1980/81 to 1997/98

\begin{tabular}{|c|c|c|c|c|c|}
\hline Year & $\begin{array}{l}\text { Direct } \\
\text { expenditure on } \\
\text { contributory } \\
\text { old age pension } \\
\text { and retirement } \\
\text { pension }\end{array}$ & $\begin{array}{l}\text { Direct } \\
\text { expenditure on } \\
\text { non-contributory } \\
\text { old age pension }\end{array}$ & $\begin{array}{l}\text { Direct } \\
\text { expenditure on } \\
\text { state pensions }\end{array}$ & $\begin{array}{l}\text { Tax expenditure } \\
\text { on occupational } \\
\text { pension schemes }\end{array}$ & $\begin{array}{l}\text { Tax } \\
\text { expenditure on } \\
\text { occ. pensions } \\
\text { as per cent of } \\
\text { direct exp. on } \\
\text { state pensions }\end{array}$ \\
\hline$£ \mathrm{~m}$ & & & & & Per cent \\
\hline $1980 / 81$ & 153.0 & 140.2 & 293.2 & 30.0 & 10.2 \\
\hline 1981/82 & 197.5 & 176.4 & 373.9 & 35.0 & 9.4 \\
\hline 1982/83 & 259.3 & 225.0 & 484.3 & 40.0 & 8.3 \\
\hline $1983 / 84$ & 293.9 & 246.5 & 540.4 & 42.0 & 7.8 \\
\hline $1984 / 85$ & 325.9 & 264.1 & 590.0 & 45.0 & 7.6 \\
\hline $1985 / 86$ & 351.7 & 273.5 & 625.2 & 53.0 & 8.5 \\
\hline $1986 / 87$ & 374.5 & 283.9 & 658.4 & 62.0 & 9.4 \\
\hline $1987 / 88$ & 399.5 & 291.2 & 690.7 & 80.0 & 11.6 \\
\hline 1988/89 & 417.2 & 291.8 & 709.0 & 89.0 & 12.6 \\
\hline $1989 / 90$ & 439.0 & 293.8 & 732.8 & 130.0 & 17.7 \\
\hline 1990/91 & 464.9 & 301.5 & 766.4 & 200.0 & 26.1 \\
\hline 1991/92 & 493.9 & 308.8 & 802.7 & 216.0 & 26.9 \\
\hline $1992 / 93$ & 529.5 & 317.2 & 846.7 & 189.0 & 22.3 \\
\hline $1993 / 94$ & 546.3 & 318.4 & 864.7 & 245.2 & 28.4 \\
\hline 1994/95 & 569.0 & 319.1 & 888.1 & 344.0 & 38.7 \\
\hline $1995 / 96$ & 597.2 & 308.8 & 906.0 & 399.0 & 44.0 \\
\hline $1996 / 97$ & 626.0 & 310.3 & 936.3 & 500.0 & 53.4 \\
\hline 1997/98 & 661.2 & 316.8 & 978.0 & 648.0 & 66.3 \\
\hline
\end{tabular}

Sources: Annual report of the Revenue Commissioners 1981 to 1999, statistical information on social welfare services 1983 to 1997, and special tabulation from the Revenue Commissioners.

non-contributory social assistance pensions tax expenditure increased from 21 per cent in 1980 ( $\_30 \mathrm{~m}$ versus f.140m) to over 200 per cent in 1997 ( $£ 648 \mathrm{~m}$ versus $£ 317 \mathrm{~m}$ ).

In terms of the combined social welfare pension schemes the cost of tax expenditure on occupational schemes increased from 10 per cent in 1980 , $£ 30 \mathrm{~m}$ versus $£ 293 \mathrm{~m}$, to over 66 per cent by $1997, £ 648 m$ versus $£ 978 m$. Given the average rates of growth of tax and direct expenditure during the period 1987-97 it would only require a few more years' growth at these rates for the cost of tax expenditure on occupational pensions to exceed the direct cost of expenditure on social welfare pensions. The introduction of Personal Retirement Savings Accounts (PRSA) with more favourable tax treatment than occupational pension schemes, as provided by the Pensions (Amendment)
Act 2002, is likely to increase the cost of tax expenditure on pensions. One effect of this may be that Exchequer support for social welfare pensions will be limited in the future while the cost of its support for private pension schemes, benefiting a much smaller number of people, will not be.

Tax expenditure on occupational and personal pensions and direct expenditure on National Insurance pensions in the UK are compared in Table 3 for the period $1986 / 87$ to $1997 / 98$. At the beginning of the period in 1986 tax expenditure on occupational and private pensions amounted to 39 per cent of National Insurance expenditure on the basic retirement pension, $f_{6} 6,800 \mathrm{~m}$ versus $\mathcal{E} 17,600 \mathrm{~m}$. By the end of the period it had fallen to 36 per cent, $\mathcal{E}_{10} 10,900 \mathrm{~m}$ versus $f 31,900 \mathrm{~m}$. With respect to means-tested assistance for the elderly, which consists almost entirely of income 
Table 3 Direct expenditure on state pensions, tax expenditure on occupational and personal pensions and direct expenditure as per cent of tax expenditure on pensions, UK 1986/87 to 1997/98

\begin{tabular}{llll}
\hline & $\begin{array}{l}\text { Cost of tax reliefs on net } \\
\text { income of occupational } \\
\text { and personal pensions } \\
\text { Em }\end{array}$ & $\begin{array}{l}\text { Direct Expenditure on } \\
\text { NI basic retirement pension } \\
\mathbf{E m}\end{array}$ & $\begin{array}{l}\text { Pension tax } \\
\text { expenditure/NI expenditure } \\
\%\end{array}$ \\
\hline $1986 / 87$ & 6,800 & 17,560 & 38.7 \\
$1987 / 88$ & 6,300 & 18,356 & 34.3 \\
$1988 / 89$ & 6,800 & 18,857 & 36.1 \\
$1989 / 90$ & 7,200 & 20,171 & 35.7 \\
$1990 / 91$ & 7,100 & 21,973 & 32.3 \\
$1991 / 92$ & 7,100 & 24,451 & 29.0 \\
$1992 / 93$ & 8,000 & 25,364 & 31.5 \\
$1993 / 94$ & 7,300 & 26,546 & 27.5 \\
$1994 / 95$ & 10,400 & 26,859 & 38.7 \\
$1995 / 96$ & 11,700 & 27,740 & 42.2 \\
$1996 / 97$ & 12,100 & 29,239 & 35.4 \\
$1997 / 98$ & 10,900 & 30,391 & 35.9 \\
\hline
\end{tabular}

Source: Sinfield ${ }^{14}$ (Table 1) and $\mathrm{HMSO}^{16}$ (Table 7.7)

support and housing and council tax benefits, Adrian Sinfield (p. 127) ${ }^{22}$ points out that in 1992/93 tax expenditure on private pensions 'cost the taxpayer almost $f_{2}, 000 \mathrm{~m}$ more than all means-tested assistance for the poorest old people.' By 1999/00 tax expenditure on pensions was costing the taxpayer $£ 2,500 \mathrm{~m}$ more than means-tested assistance for the elderly.

\section{Distribution of tax expenditure on pensions in Ireland and the UK}

With the reduction in both Ireland and Britain in recent years of mortgage interest relief, the tax reliefs for pension funds are now the most costly items in the Revenue Commissioners and Inland Revenue lists of income tax expenditures. ${ }^{23}$ Individual tax payers are obliged to include details on their annual income tax return of mortgage interest payments for which they are claiming tax reliefs. Consequently, the Revenue Commissioners have information on the distribution of these tax reliefs by income class. Unfortunately, because of the way in which the reliefs on occupational pension contributions and pension fund income are given, there is no official information on the value of the tax relief accruing by income groups for contributions to occupational pension funds. However, a household survey carried out by the ESRI in $1994^{24}$ contains information on weekly gross earnings of employees who are members of any type of pension scheme. These data permit us to estimate the level and distribution for Ireland of tax reliefs on contributions to occupational pension schemes by employees.

Information on the distribution of pension contribution tax relief by income group has been produced for the UK by Agulnik and Le Grand ${ }^{25}$ using unpublished data supplied by the Inland Revenue. The data for Ireland and the UK are used in Table 4 to show by income deciles the percentage of employees in Ireland who belong to an occupational pension scheme and the percentage of taxpayers in the UK who claim tax relief on contributions to an occupational or personal pension scheme.

The table shows that coverage of 
Table 4 Percentage of employees in Ireland in 1994 belonging to occupational pension schemes and percentage of taxpayers in the UK in 1996/97 claiming tax relief for contributions to an occupational or personal pension ranked by income deciles

\begin{tabular}{lcc}
\hline Decile & Ireland & UK \\
\hline Bottom & 0.5 & 20.8 \\
Second & 8.9 & 25.7 \\
Third & 16.5 & 26.3 \\
Fourth & 35.6 & 37.7 \\
Fifth & 50.1 & 48.4 \\
Sixth & 59.7 & 56.3 \\
Seventh & 70.5 & 61.8 \\
Eighth & 79.4 & 68.2 \\
Ninth & 89.0 & 78.8 \\
Top & 92.7 & 80.7 \\
\hline
\end{tabular}

Source: Ireland, Hughes ${ }^{13}$ (Table 8); UK, derived from Agulnik and Le Grand ${ }^{25}$ (Table A1.)

occupational pension schemes is quite good for the top three deciles in both countries; reasonably good for middle income employees in the fifth, sixth, and seventh deciles with from around 50 to 70 per cent having a pension entitlement; rather poor for low income employees in the UK for the bottom, second, third, and fourth deciles with only 20 to 40 per cent having an entitlement, and very poor for the lowest income deciles in Ireland with virtually no occupational pension coverage for the bottom income decile and only 10 to 35 per cent being covered in the second to fourth deciles. ${ }^{26}$ The differences between Ireland and the UK are most pronounced towards the bottom and top of the earnings distribution. The difference for the lowest income deciles may be partly due to the fairly uniform take-up by income decile of personal pensions in the UK.

The only data available to assess the distribution of tax support in Ireland for occupational pensions come from the ESRI Living in Ireland survey. It contains information on the size of the employee contribution to occupational pension schemes but unfortunately not on the employer contribution. An estimate of the value of the tax relief given to employees can be derived by income class, which will show whether the tax support provided for employee contributions is progressive, proportional, or regressive relative to income. The estimates of the value of the tax expenditure as a percentage of income take account of marital status, the standard personal allowances, and the relevant marginal tax rates. The aggregate value of pension contributions and of the tax relief are averaged across everyone in the income class whether they make a pension contribution or not. Data are available from the Inland Revenue for the UK on the distribution by income group of employees' contribution relief for occupational and personal pensions and Agulnik and Le Grand ${ }^{25}$ gross up employees' contributions to estimate the value of tax relief on employers' contributions. Lack of data for Ireland and the UK precludes estimates of the distributional effect of tax reliefs on lump sums or investment income. Table 5 shows that tax support for private pension contributions is regressive in both Ireland and the UK.

The value of the relief on employee contributions alone in Ireland expressed as a percentage of weekly income increases from less than 0.06 per cent at 
Table 5 Tax relief on employee contributions to occupational pension schemes in Ireland in 1994 and on employee and employer contributions to private pension plans in the UK in 1996/97 as a percentage of income by income decile

\begin{tabular}{lll}
\hline Income decile & Ireland (Employee contribution) & $\begin{array}{l}\text { UK (Employee and employer } \\
\text { contributions to occupational and person } \\
\text { pensions) }\end{array}$ \\
\hline Bottom & 0.06 & 0.71 \\
2 & 0.11 & 0.80 \\
3 & 0.18 & 0.83 \\
4 & 0.41 & 1.33 \\
5 & 0.76 & 1.39 \\
6 & 0.79 & 1.59 \\
7 & 0.85 & 1.69 \\
8 & 1.23 & 1.82 \\
9 & 1.72 & 2.29 \\
Top & 1.62 & 3.64 \\
\hline
\end{tabular}

Source: Ireland, Hughes ${ }^{13}$ (Table 8); UK, derived from Agulnik and Le Grand ${ }^{25}$ (Table A1.)

Note: These figures do not include the value of tax reliefs on lump sum payments or investment income.

the bottom of the income distribution to around 0.8 per cent in the middle and to about 1.6 per cent at the top. Thus, those on the lowest incomes, less than IR $\mathcal{L}_{41.00}$ per week, receive hardly any benefit from the tax relief on occupational pension contributions while those on the highest incomes, over IR $£ 720$ per week, benefit to the extent of 1.6 per cent of their weekly income. For the UK, the value of tax relief on both employee and employer contributions as a percentage of income rises from 0.71 per cent for those in the bottom income decile earning less than 690 per week to 3.6 per cent for those in the top income decile earning almost 6870 per week on average. Of this tax relief, Table 6 shows that the top 10 per cent of earners in Ireland receive almost 40 per cent of the benefit, while in the UK they receive over 50 per cent of the benefit. In Ireland the bottom 10 per cent of earners receive only 0.1 per cent of the tax benefit while in the UK they receive just 1 per cent of the tax benefit.

There are two main reasons for the regressivity of tax expenditure on private pensions, as Agulnik and Le Grand ${ }^{25}$ point out. The first is that membership of occupational pension schemes increases strongly with income, as we have shown above. The second is that the tax relief is given at the marginal rate of tax. Hence, the value of the tax relief as a percentage of income rises as income rises. The interaction of these two factors results in a steady increase in the absolute value of the tax relief on occupational pension contributions as the absolute value of income rises.

The concentration of pension tax expenditures in Ireland and the UK on the highest paid taxpayers is a striking example of the 'upside-down' nature of tax expenditures whereby, as Sinfield ${ }^{14}$ (p. 20) notes:

'The benefit is greater, the higher the income and the higher the marginal tax rate which is avoided as a result of the tax mechanism. The greatest beneficiaries are those who have the least needs by any measure used in social policy analysis.'

\section{Summary and conclusions}

The evidence presented in this paper shows that the annual cost of tax expenditure on pensions is substantial in 
Table 6 Distribution of tax relief on employee contributions to occupational pension schemes in Ireland in 1994 and on employee and employer contributions to private pension plans in the UK in 1996/97 by income decile

\begin{tabular}{lcc}
\hline Income decile & Ireland (Employee contribution) & $\begin{array}{l}\text { UK (Employee and employer } \\
\text { contributions to occupational and person } \\
\text { pensions) }\end{array}$ \\
\hline Bottom & 0.1 & 1.0 \\
2 & 0.4 & 1.3 \\
3 & 0.8 & 1.2 \\
4 & 2.5 & 3.9 \\
5 & 5.4 & 4.5 \\
6 & 6.5 & 5.3 \\
7 & 8.3 & 8.1 \\
8 & 13.9 & 7.5 \\
9 & 24.0 & 15.6 \\
Top & 38.0 & 51.6 \\
Total & 100.0 & 100.0 \\
\hline
\end{tabular}

Source: Ireland, Hughes ${ }^{13}$ (Table 8); UK, derived from Agulnik and Le Grand ${ }^{25}$ (Table A1.)

Note: These figures do not include the value of tax reliefs on lump sum payments or investment income.

Ireland, where it amounted to 1.2 per cent of GDP in 1997, and the UK, where it was not far off 1.5 per cent of GDP in the same year. Hence, the assumption that private pensions can be provided at little cost to the Exchequer is not correct. Considering pension tax expenditure in relation to direct expenditure on public pension programmes, the evidence shows that tax expenditure in Ireland on occupational pensions now substantially exceeds the cost of the means-tested non-contributory pension scheme and amounts to about two-thirds of government expenditure on social insurance pension schemes. If present trends in pension tax expenditure continue, it may exceed in a few years time combined expenditure on social assistance and social insurance old age pensions. In the UK the cost of pension tax reliefs substantially exceeds the cost of means-tested income and housing support for the elderly and amounts to about one-third of direct expenditure on basic National Retirement pensions.

Examination of membership of private pension schemes shows that tax incentives for pension saving result in high coverage rates for middle and high income taxpayers, but poor coverage rates for low income taxpayers in both Ireland and the UK. Evidence relating to the distribution of pension tax expenditure shows that the present tax treatment of private pensions is inequitable as about two-thirds of the benefits accrue to the top two income deciles in both countries and 3 per cent or less to the bottom two deciles.

PENSIM, the microsimulation model of the UK pension system, was used by the Pension Provision Group at the start of the British government's latest Pension Review to look at the effect of current policies on pension provision in 2025 . The Group examined how the distribution of pension incomes is likely to change over this period. It concluded $^{27}$ that:

'The bigger role for earnings-related pensions - state and non-state - which has been a feature of the policy of governments for several decades, must inevitably lead to more inequality in income in old age'.

The pattern of pension provision in Ireland in the future is likely to be similar in view of the reliance on occupational pension schemes and the 
concentration of tax reliefs for pension saving on the highest income deciles.

Proposals for containing the cost of public pension systems in Europe by relying on greater private pension provision in the future can learn from experience in Ireland and Britain, and other countries that rely on private pensions, that using tax incentives to promote private pension provision could impose substantial costs on the Exchequer. The regressive nature of such incentives means that all taxpayers have to pay more taxes to provide benefits which accrue overwhelmingly to higher income taxpayers.

\section{Acknowledgment}

This paper is based on recent work on pension tax expenditure in Ireland by Hughes $^{13}$ and in the UK by Sinfield ${ }^{14}$ and Agulnik and Le Grand. ${ }^{25}$ I am grateful to Adrian Sinfield for stimulating my interest in tax expenditure on pensions, for helpful discussions on measurement issues, and for supplying data on the cost of pension tax reliefs for the UK. I am also grateful to him and to participants at an LSE conference in January 2002 on Modelling Policy for an Ageing Europe for comments on an earlier draft.

\section{References}

1 For Ireland see Hughes, G. and Whelan B. (1996) 'Occupational and personal pension coverage 1995', Economic and Social Research Institute, Dublin.

2 For the UK see HMSO (2001) 'Occupational pension schemes 1995: Tenth survey by the Government Actuary', Stationery Office, London.

3 The ILO provides evidence of such outcomes in Chile where the public pension system was replaced with a compulsory private pension system. ILO (2000) 'Report of the committee of experts on the application of conventions and recommendations: General report and observations concerning particular countries', International Labour Office, Geneva.

4 See Feldstein, M. (ed.) (1998) 'Privatizing social security', The University of Chicago Press, Chicago.
5 National Pensions Board (1988) 'Report on the tax treatment of occupational pension schemes', Stationery Office, Dublin.

6 World Bank (1994) 'Averting the old age crisis: Policies to protect the old and promote growth', Oxford University Press, Oxford.

7 Edey, M. and Simon, J. (1998) 'Australia's retirement income system', in Feldstein, M. (ed.) 'Privatizing social security', The University of Chicago Press, Chicago.

8 Budd, A. and Campbell, N. (1998) 'The roles of the public and private sectors in the UK pension system', in Feldstein, M. (ed.) 'Privatizing social security', The University of Chicago Press, Chicago.

9 Feldstein, M. and Samwick, A. (1998) 'The transition path in privatizing social security', in Feldstein, M. (ed.) 'Privatizing social security', The University of Chicago Press, Chicago.

10 Borsch-Supan, A. (2000) 'Pension reform in Germany', World Economics, Vol. 1, No. 1.

11 Mantel, J. and Bowers, D. (2000) 'European pension reforms: A study by Merrill Lynch', World Economics, Vol. 1, No. 1.

12 Surrey, S. (1973) 'Pathways to tax reform', Harvard University Press, Cambridge, Mass.

13 Hughes, G. (2001) 'The cost and distribution of tax expenditure on occupational pensions in Ireland', incorporated in 'The thirty-first Geary Lecture', The Economic and Social Research Institute, Dublin.

14 Sinfield, A. (2000) 'Tax benefits in non-state pensions', European Journal of Social Security, Vol. 2, No. 2, pp. 137-167.

15 If tax reliefs for pension saving were eliminated the Exchequer would not necessarily benefit to the full extent of the value of the tax relief because of behavioural changes by savers. A similar interaction effect applies to direct public expenditure. For example, the Exchequer would not save the full cost of a social insurance pension scheme by eliminating it as behavioural changes by some beneficiaries would make them eligible for benefits under other programmes. Neither argument means that the cost of tax expenditure on private pensions or direct expenditure on social insurance pensions should not be given as the full cost.

16 HMSO (2001) 'Inland Revenue statistics 2000', The Stationery Office, London.

17 OECD (1992) 'Private pensions and public policy', Organisation for Economic Cooperation and Development, Paris.

18 HMSO (1998) 'We all need pensions: The prospects for pension provision', The Stationery Office, London.

19 Pensions Board (1998) 'Securing retirement income', The Pensions Board, Dublin.

20 The target is to increase coverage from 54 per cent of those aged 30-65 at work in 1995 to 70 per cent over a period of ten years or more.

21 Pensions Board (1997) National pensions policy initiative consultation document, The Pensions Board, Dublin.

22 Sinfield, A. (1997) 'Social protection versus tax 
benefits', in European Institute of Social Security, 'Social protection of the next generation in Europe', Kluwer Law International, The Hague.

23 Structural reliefs are assumed to be part of the benchmark tax system.

24 Callan, T., Nolan, B., Whelan, B., Whelan, C. and Williams, J. (1996) 'Poverty in the 1990s: Evidence from the 1994 living in Ireland survey', Oaktree Press, General Research Series No. 146.

25 Agulnik, P. and Le Grand, J. (1998) 'Tax relief and partnership pensions', Fiscal Studies, Vol. 19, No. 4.

26 The pattern is similar in Ireland when pension coverage rates are estimated by age group. For example, the coverage rate for those under 30 was 1.3 per cent for the first decile and 79 per cent for the 10th decile.

27 HMSO (1998) 'Partnership in pensions: A new contract for welfare', The Stationery Office, London, p. 109. 